\title{
Detection of rainbow trout antibodies against viral haemorrhagic septicaemia virus (VHSV) by neutralisation test is highly dependent on the virus isolate used
}

\author{
J. M. Fregeneda-Grandes ${ }^{1,2}$, N. J. Olesen ${ }^{1, *}$ \\ ${ }^{1}$ National Veterinary Institute, Technical University of Denmark, Hangøvej 2, 8200 Århus N, Denmark \\ ${ }^{2}$ Present address: Departamento de Patología Animal-Sanidad Animal, Universidad de León, 24071 León, Spain
}

\begin{abstract}
Three serological tests, enzyme linked immunosorbent assay (ELISA), $50 \%$ plaque neutralisation test (50\%PNT) and Western blotting (WB), were used to detect antibodies against viral haemorrhagic septicaemia virus (VHSV) in 50 rainbow trout broodstock from a rainbow trout farm endemically infected with VHS but with no clinical signs of infection. When the sera were examined by $50 \%$ PNT using the VHSV reference isolate DK-F1 or the heat attenuated DK-F25 mutant strain, no neutralizing antibodies were found. In contrast, when one of the virus isolates from the farm (homologous virus) was used in the $50 \%$ PNT, $90 \%$ of the fish were found to be positive. By examining a panel of different VHSV isolates in 50\%PNT, it was demonstrated that the virus isolate used as test antigen could significantly affect the sensitivity and titre determination in 50\%PNT for detection of rainbow trout antibodies against VHSV. When the sera were examined for the presence of VHSV antibodies by ELISA or WB, $61 \%$ were found to be positive. When conducting WB analysis, the viral glycoprotein was the protein most frequently recognized, followed by the viral nucleoprotein.
\end{abstract}

KEY WORDS: VHSV $\cdot$ Trout antibody $\cdot$ Serology $\cdot$ Plaque neutralisation $\cdot$ ELISA

\section{INTRODUCTION}

Viral haemorrhagic septicaemia (VHS) is a serious viral disease affecting a range of fish species (Wolf 1988). The etiological agent, viral haemorrhagic septicaemia virus (VHSV), is included in the genus Novirhabdovirus of the Rhabdoviridae family (Van Regenmortel et al. 2000). VHS has occurred endemically in the continental part of Europe for decades, and in the past 15 yr many isolations of VHSV have been made from an increasing number of free-living marine and freshwater fish species (Skall et al. 2005), showing that the virus is much more widespread than previously anticipated. VHS has an important economic impact for European rainbow trout farming and is included in the Office International de Epizooties (OIE) list of notifiable diseases (OIE 2004) and in List II of EU Council
Directive 91/67/EEC, Annex A (Anon. 1991). Surveillance programs are based on virus isolation in cell cultures and identification by immunological techniques.

Antibodies against VHSV in rainbow trout were first reported in the 1970s (Jørgensen 1971, 1974). Since then, several studies have demonstrated the efficacy of different serological techniques, like immunofluorescence (IF), enzyme linked immunosorbent assay (ELISA), plaque neutralisation test (50\%PNT) and Western blotting (WB), for the detection and characterization of rainbow trout antibodies against salmonid rhabdoviruses under experimental and field conditions (Enzmann \& Konrad 1990, 1993, Jørgensen et al. 1991, Olesen et al. 1991, Lorenzen et al. 1993, HattenbergerBaudouy et al. 1995). These studies suggest that serological techniques could be developed and used as epidemiological and diagnostic tools as well as for con- 
trol and surveillance, but more work is needed for standardization and validation in order to include serological tests in surveillance programs (LaPatra 1996) and in international diagnostic manuals such as the OIE Manual of Diagnostic Tests for Aquatic Animals. Surveillances based on serological tests have several advantages compared with virus isolation, especially in cases were water temperature is too high for virus isolation and in endemically infected populations without clinical symptoms of disease. However, the disadvantage of serological test is the slow development of fish antibodies after infection, especially at low water temperature.

In the present study we used 3 different serological tests-ELISA, $50 \%$ PNT and WB - to detect antibodies against VHSV in rainbow trout broodstock from a Danish farm endemically infected with VHSV. Different strains of VHSV as antigen source in $50 \%$ PNT were tested in order to assess how they could affect the test sensitivity and titre determination.

\section{MATERIALS AND METHODS}

Rainbow trout sera. Individual blood samples were obtained by puncture of the caudal vein of 50 rainbow trout Oncorhynchus mykiss (Walbaum) broodstock from a fish farm endemically infected with VHSV situated in the south-western part of Denmark. Another 50 samples were taken from a fish farm free of VHSV but infected with infectious pancreatic necrosis virus (IPNV), and used as negative controls. Blood samples were placed at $4{ }^{\circ} \mathrm{C}$ and allowed to clot overnight. The specimens were centrifuged at $1000 \times g$ for $45 \mathrm{~min}$, complement inactivated at $45^{\circ} \mathrm{C}$ for 30 min (Olesen \& Jørgensen 1986), and stored at $-80^{\circ} \mathrm{C}$ until examination.

Virological examination. After blood sampling the fish were killed and organ samples (anterior kidney, spleen and heart) were collected for virological examination. The samples were prepared and processed according to the standard diagnostic procedures outlined by EU Commission Decision 2001/183/EC (Anon. 2001) and inoculated into BF-2 cells in 24 -well plates. Plates were incubated at $15^{\circ} \mathrm{C}$ and observed for cytopathic effect (CPE) for $7 \mathrm{~d}$; a second passage was made if no CPE occurred within the first $7 \mathrm{~d}$. When CPE occurred, virus identification was attempted by ELISA (Olesen \& Jørgensen 1991). The neutralisation pattern (serogroups) of the isolated VHS viruses were determined by $50 \%$ PNT using a panel of 4 monoclonal antibodies (MAbs) and 1 rabbit antiserum, as described by Olesen et al. (1993).

Viruses and fish cell lines. The following $17 \mathrm{VHSV}$ isolates from freshwater and the marine environment, representing all 3 neutralisation patterns of VHSV
(Olesen et al. 1993), were selected and examined: (1) the first Danish VHSV isolate DK-F1 and its heatadapted mutant strain DK-F25, and the highly pathogenic rainbow trout pathogenic isolate DK-3592B, which all belong to Serogroup I; (2) the Danish isolate DK-5131 and the French isolate F403, both belonging to Serogroup II, (3) 7 Danish isolates (DK-5151, DK6137 and 5 homologous isolates obtained in the present study from the fish farm DK-201433-10, -15, -40, -42 and -49), 1 French isolate $H$ 11225, and 1 Czech isolate 200317, all 9 of which belong to Serogroup III, and finally (4) 3 isolates from wild marine fish species -2 from the Baltic Sea close to Denmark (DK-1p8 and DK1p49), and 1 from the USA, Makah. Details and sources of the virus isolates used are given in Table 1.

All viruses except the marine isolates, were propagated in epithelioma papulosum cyprini (EPC) cells

Table 1. Characteristics and origin of virus isolates used in this study. VHSV I, II, III: VHSV with neutralisation pattern Type I, II or III, respectively (Olesen et al. 1993). VET-DTU: National Veterinary Institute, Technical University of Denmark

\begin{tabular}{|c|c|c|c|}
\hline Virus isolate & $\begin{array}{l}\text { Host } \\
\text { species }\end{array}$ & $\begin{array}{l}\text { Country/ } \\
\text { area }\end{array}$ & Source \\
\hline \multicolumn{4}{|l|}{ VHSV I } \\
\hline DK-F1 & $\begin{array}{l}\text { Rainbow } \\
\text { trout }\end{array}$ & Denmark & Jensen (1965) \\
\hline DK-F25 & $\begin{array}{l}\text { Rainbow } \\
\text { trout }\end{array}$ & Denmark & $\begin{array}{l}\text { de Kinkelin \& } \\
\text { Bearzotti (1981) }\end{array}$ \\
\hline DK-3592B & $\begin{array}{c}\text { Rainbow } \\
\text { trout }\end{array}$ & Denmark & $\begin{array}{l}\text { Lorenzen et al. } \\
\text { (1990) }\end{array}$ \\
\hline \multicolumn{4}{|l|}{ VHSV II } \\
\hline DK-5131 & $\begin{array}{l}\text { Rainbow } \\
\text { trout }\end{array}$ & Denmark & Olesen et al. (1993) \\
\hline F-403 & $\begin{array}{l}\text { Rainbow } \\
\text { trout }\end{array}$ & France & $\begin{array}{l}\text { J. Castric, AFSSA, } \\
\text { Brest, unpubl. (2002) }\end{array}$ \\
\hline \multicolumn{4}{|l|}{ VHSV III } \\
\hline $\begin{array}{l}\text { DK- } 201433 \\
\text { N-10,-15, } \\
-40,-42,-49\end{array}$ & $\begin{array}{l}\text { Rainbow } \\
\text { trout }\end{array}$ & Denmark & This study \\
\hline DK-5151 & $\begin{array}{l}\text { Rainbow } \\
\text { trout }\end{array}$ & Denmark & Olesen et al. (1993) \\
\hline DK-6137 & $\begin{array}{l}\text { Rainbow } \\
\text { trout }\end{array}$ & Denmark & $\begin{array}{l}\text { NET-DTU } \\
\text { unpubl. (1991) }\end{array}$ \\
\hline F-H11225 & $\begin{array}{l}\text { Rainbow } \\
\text { trout }\end{array}$ & France & $\begin{array}{l}\text { J. Castric, AFSSA, } \\
\text { Brest, unpubl. (1998) }\end{array}$ \\
\hline $\begin{array}{l}\text { CZ 2077- } \\
200317\end{array}$ & $\begin{array}{l}\text { Rainbow } \\
\text { trout }\end{array}$ & $\begin{array}{l}\text { Czech } \\
\text { Republic }\end{array}$ & $\begin{array}{l}\text { T. Vésely, VRI, } \\
\text { Brno, unpubl. (2000) }\end{array}$ \\
\hline \multicolumn{4}{|l|}{ Marine VHSV } \\
\hline DK-1p8 & Herring & Baltic Sea & $\begin{array}{l}\text { Mortensen et al. } \\
\text { (1999) }\end{array}$ \\
\hline DK-1p49 & Herring & Baltic Sea & $\begin{array}{l}\text { Mortensen et al. } \\
\text { (1999) }\end{array}$ \\
\hline RBV-'Makah' & $\begin{array}{l}\text { Coho } \\
\text { salmon }\end{array}$ & USA & $\begin{array}{l}\text { Brunson et al. } \\
\text { (1989) }\end{array}$ \\
\hline
\end{tabular}


(Fijan et al. 1983) at $15^{\circ} \mathrm{C}$ using Eagles MEM supplemented with $10 \%$ foetal bovine serum (FBS), Tris buffer and antibiotics in standard concentrations. The marine isolates were propagated in BF-2 cells (Wolf et al. 1966). Supernatants from infected cell cultures showing complete CPE were clarified by centrifugation at $4000 \times g$ for $15 \mathrm{~min}$, filtered through $0.45 \mu \mathrm{m}$ pore filters, divided into aliquots, and frozen at $-80^{\circ} \mathrm{C}$ until used as antigen in serological tests.

ELISA. The ELISA used to detect rainbow trout antibody against VHSV was performed according to the general principles of indirect ELISA described by Voller et al. (1979) and followed the ELISA technique previously described (Jørgensen et al. 1991, Olesen et al. 1991). The ELISA test used was an antigen-capture ELISA, making each fish serum its own negative control by incubating the sera on wells with and without virus, respectively, and by only taking differences in optical density into account. This is necessary due to the sticky nature of fish antibodies, which have a tendency to bind non-specifically to the plates (Olesen et al. 1991). Briefly, microtitre plates (Nunc) were first coated with protein-A purified rabbit anti-virus immunoglobulin (Ig) diluted in carbonate buffer. After washing the plates with PBS containing $0.05 \%$ Tween20 (PBS-T), the VHSV suspension diluted to 1:10 in PBS-T with $1 \%$ bovine serum albumin (PBS-T-BSA) was added and incubated for $1 \mathrm{~h}$ at room temperature. After washing with PBS-T and blocking for $2 \mathrm{~h}$ at room temperature with PBS-T-BSA, the plates were incubated overnight at $4^{\circ} \mathrm{C}$ with serial 2-fold dilutions (1:40 to $1: 10240$ ) of trout serum in PBS-T-BSA. Positive- and negative-control trout sera were included on each plate. Following another washing step with PBS-T, the plates were incubated for $1 \mathrm{~h}$ at room temperature with MAb 4C10 against rainbow trout IgM (Thuvander et al. 1990), followed by another washing cycle and incubation for $1 \mathrm{~h}$ at room temperature with horseradishperoxidase (HRP)-conjugated rabbit antiserum against mouse Ig (Dako A/S). After a final washing step, the bound enzyme was visualized by addition of $\mathrm{H}_{2} \mathrm{O}_{2}$ orthophenyline diamine substrate (Sigma-Aldrich), and the reaction was stopped after 15 min at room temperature by addition of $1 \mathrm{M} \mathrm{H}_{2} \mathrm{SO}_{4}$. Absorbance was measured spectrophotometrically in a Titertek Multiscan reader at a wavelength of $492 \mathrm{~nm}\left(\mathrm{~A}_{492}\right)$. The ELISA titre of a trout serum was defined as a reciprocal value of the highest serum dilution giving a difference in absorbance of 0.5 or more between wells with and without virus, respectively.

$\mathbf{5 0} \%$ PNT. Prior to neutralisation, the virus isolates were plaque-titrated in microplates with EPC cells using overlay medium containing $1 \%$ methylcellulose in order to determine the dilution to be used in the test. The $50 \%$ PNT with complement addition was per- formed in 96-well microtitre plates as previously described (Olesen \& Jørgensen 1986) but with some modifications. Briefly, $0.05 \mathrm{ml}$ (per well) of serial 2-fold dilutions of trout serum in dilution medium (Eagles NEM with Tris buffer and 5\% FBS), beginning with a dilution ratio of 1:10, were mixed in round bottom, 96well microplates (Nunc) with an equal volume of trout complement diluted to 1:30. After incubation for $30 \mathrm{~min}$ at $15^{\circ} \mathrm{C}$ on a rocker platform, $0.1 \mathrm{ml}$ of virus dilution adjusted to $8 \times 10^{3} \mathrm{PFU} \mathrm{ml}^{-1}$ was added to each well and the plate was incubated overnight at $15^{\circ} \mathrm{C}$ on a rocker platform. Each serum-complement-virus mixture was then adsorbed to 2 replicate wells $(0.01 \mathrm{ml}$ per well) with monolayer EPC cells in 96-well microplates (Life Technologies) for $1 \mathrm{~h}$ at $15^{\circ} \mathrm{C}$. The cell cultures were then overlaid with $1 \%$ methyl cellulose medium and incubated for $5 \mathrm{~d}$ at $15^{\circ} \mathrm{C}$. Finally, the cells were fixed in $10 \%$ P-buffered formaldehyde $(0.15 \mathrm{ml}$ per well, $3 \mathrm{~h}$ at room temperature), followed by 10 washes with tap water and staining with $0.5 \%$ crystal violet (0.05 ml per well, $30 \mathrm{~min}$ at room temperature). After 10 more washes, the microplates were air-dried and the plaques counted by placing the plates on a light table. The $50 \%$ PNT titre was calculated as the reciprocal value of the highest trout serum dilution causing a $50 \%$ reduction of the average number of plaques in control cultures inoculated with normal trout serum, complement and virus.

In the $50 \%$ PNT with the marine VHSV isolates, serum-complement-virus mixture was adsorbed onto BF-2 cells instead of EPC cells for $1 \mathrm{~h}$ at $15^{\circ} \mathrm{C}$, overlaid with $1 \%$ methyl cellulose medium and incubated for only $24 \mathrm{~h}$ at $15^{\circ} \mathrm{C}$. Then, the infected cells were visualized by immunostaining using MAb IP5B11 against the VHSV N protein as the first antibody layer, HRP-conjugated as the second antibody layer and 3-amino-9ethylcarbazole as the substrate (Lorenzen et al. 1988, 1990).

Western blotting (WB). A WB analysis was performed in order to identify individual virus proteins recognized by the trout sera. Purification of viral proteins, SDS-PAGE and transfer methods have been previously described (Lorenzen et al. 1988, 1993). The WB experiments were carried out using VHSV DK-F1 and without 2-mercaptoethanol in the sample buffer (nonreduced conditions). Trout sera were diluted to 1:50 in PBS-T-BSA and incubated overnight at $4^{\circ} \mathrm{C}$ with strips of nitrocellulose membrane with viral proteins. After incubation, the strips were washed 3 times for $5 \mathrm{~min}$ with PBS-T. Then, the strips were incubated for $1 \mathrm{~h}$ at room temperature with MAb 4C10 against rainbow trout IgM, followed by 3 washes with PBS-T and incubation for $1 \mathrm{~h}$ at room temperature with HRP-conjugated rabbit anti mouse Ig. After a final washing step, the bands reacting with the sera were visualized by 
Table 2. Detection of VHSV and antibodies against VHSV by ELISA, $50 \%$ PNT and WB in 50 rainbow trout from an endemically VHSV-infected farm; ns: no sample. G: viral glycoprotein, N: viral nucleoprotein, M1 and M2: viral matrix protein 1 and 2

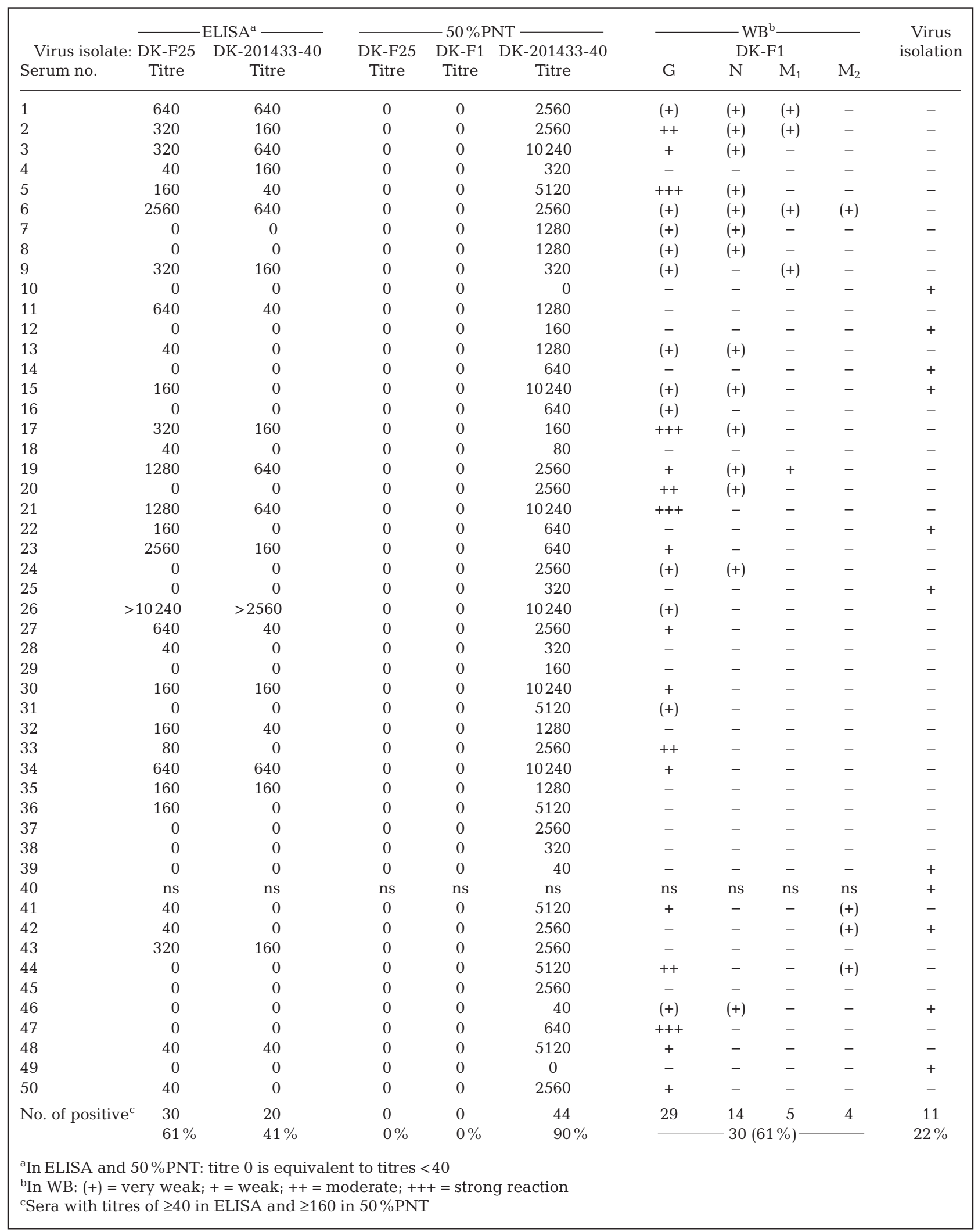


3-amino-9-ethylcarbazole in sodium acetate buffer (0.1 M, pH 5.5). The reaction was stopped after $30 \mathrm{~min}$ at room temperature by washing the strips with distilled water.

\section{RESULTS}

\section{Clinical and virological examination}

None of the 50 fish collected from the endemically VHSV-infected farm showed any clinical signs of VHS. However, 11 fish (22\%) were shown by cell cultivation to be positive for VHSV (Table 2). The neutralisation patterns of these VHSV isolates were examined and revealed that all belong to Serogroup III (data not shown). None of the 50 fish collected from the VHSVfree farm showed any clinical signs of diseases; IPNV was isolated from 2 fish.

\section{Detection of antibodies}

When sera from the VHSV-infected farm were examined by $50 \%$ PNT using VHSV DK-F1 or the heat attenuated DK-F25 mutant, no neutralizing antibodies were found. In contrast, when one of the virus isolates from the farm (DK-201433-40 from Trout No. 40) was used, $90 \%$ (44 from 49) of the fish had neutralizing antibody titres of 160 or more and were thus considered positive. The titres ranged from 40 to 10240 and most of the sera had titres around 2560 (median titre 2560) (Table 2).

When the sera were examined by ELISA using the VHSV DK-F25 as antigen, 30 (61\%) were positive, with titres ranging from 40 to 2560 except one that was higher than 10240 (Table 2). The median titre was 160. Seven of the sera had a titre of 40 ; however, in 4 of sera, the $\mathrm{A}_{492}$ value was very close to the cut-off value. In the group of positive sera, most (16 from 30 ) had titres ranging from 160 to 640 . When the homologous VHSV isolate DK-201433-40 was used in the ELISA test, only 20 of the 49 sera ( $41 \%$ ) were found positive, with titres ranging from 40 to 2560 (median titre 160) (Table 2). Most of the sera that were negative with the DK-201433-40 isolate but positive with DK-F25 had low titres (40) with the latter.

When WB was performed, positive bands were visualised in 30 of the sera $(61 \%)$ but different reaction patterns were observed. Viral glycoprotein $(\mathrm{G})$ was the protein most frequently recognized (in 29 of the 30 sera with positive reactions), followed by the nucleoprotein (N) (14 of 30 sera). The membrane proteins $\left(M_{1}, M_{2}\right)$ were recognized by only 5 and 4 sera, respectively. Of the 49 sera analysed, 19 (39\%) did not react with any viral proteins (Table 2). WB only tested the reaction against one virus isolate (DK-F1).

In order to examine the specificity of the serological techniques, 50 broodstock fish sera collected in an approved VHS-free farm were examined (this farm had been officially tested and assessed to be free of VHS for more than $30 \mathrm{yr}$ ). The farm is, however, infected with IPN. All sera from this farm were negative for antibodies against VHSV, except one that had a weak positive reaction in ELISA at a titre of 40 . When these sera were examined for the presence of antibodies against IPNV by ELISA (plates coated with proteinA purified rabbit anti-IPNV and a virus suspension of the reference strain Sp (Spjarup) of IPNV diluted to $1: 5), 13$ of them (26\%) were positive with titres ranging from 80 to 10240 (data not shown).

\section{Effect of virus isolates used as antigen in $50 \%$ PNT}

When a panel of 13 different VHSV isolates was used in $50 \%$ PNT for detection of neutralising antibodies in 5 selected trout sera, significant differences were observed among the virus isolates included (Table 3). The highest titres were observed by using the homologous VHSV DK-201433-40 in the 50\%PNT. Trout Serum No. 8 recognised this isolate very specifically, with no cross-neutralisation to any of the other virus isolates. The only VHSV isolates that were not neutralised by any of the sera were the DK-F1 and DK-F25

Table 3. 50\%PNT titres using different VHSV isolates and 5 sera from a rainbow trout farm endemically infected with VHSV. VHSV I, II, III: VHSV with neutralisation pattern Type I, II or III, respectively (Olesen et al. 1993); titre 0 is equivalent to titres $<40$

\begin{tabular}{|c|c|c|c|c|c|}
\hline $\begin{array}{l}\text { Virus } \\
\text { isolate }\end{array}$ & 6 & 8 & $\begin{array}{r}\text { erum } n \\
21\end{array}$ & 26 & 47 \\
\hline \multicolumn{6}{|l|}{ VHSV I } \\
\hline DK-F1 & 0 & 0 & 0 & 0 & 0 \\
\hline DK-F25 & 0 & 0 & 0 & 0 & 0 \\
\hline DK-3592B & 1280 & 0 & 2560 & 640 & 320 \\
\hline \multicolumn{6}{|l|}{ VHSV II } \\
\hline DK-5131 & 640 & 0 & 640 & 40 & 0 \\
\hline F-403 & 2560 & 0 & 2560 & 80 & 2560 \\
\hline \multicolumn{6}{|l|}{ VHSV III } \\
\hline DK-201433-40 & 1280 & 640 & 5120 & 5120 & 1280 \\
\hline DK-5151 & 320 & 0 & 160 & 640 & 640 \\
\hline DK-6137 & 160 & 0 & 320 & 320 & 320 \\
\hline F-H11225 & 1280 & 0 & 80 & 640 & 0 \\
\hline CZ 2077-200317 & 2560 & 0 & 5120 & 160 & 1280 \\
\hline \multicolumn{6}{|l|}{ Marine VHSV } \\
\hline DK-1P8 & 1280 & 0 & 320 & 160 & 0 \\
\hline DK-1P49 & 320 & 0 & 1280 & 0 & 0 \\
\hline RBV-'Makah' & 0 & 0 & 0 & 0 & 0 \\
\hline
\end{tabular}


Table 4. $50 \%$ PNT titres using 5 homologous VHSV isolates and 16 sera from a rainbow trout farm endemically infected with VHSV

\begin{tabular}{|lrrrrr|}
\hline $\begin{array}{l}\text { Serum } \\
\text { no. }\end{array}$ & DK- & DK- & \begin{tabular}{c} 
DK- \\
\multicolumn{7}{c|}{ DKS isolate }
\end{tabular} & DK- & DK- \\
\hline \multicolumn{7}{c}{$201433-10$} & $201433-15$ & $201433-40$ & $201433-42$ & $201433-49$ \\
8 & 320 & nd & 640 & nd & 640 \\
10 & 40 & 0 & 0 & 40 & 0 \\
12 & 40 & 40 & 160 & 80 & 40 \\
14 & 160 & 160 & 640 & 320 & 160 \\
15 & $>5120$ & $>5120$ & $>5120$ & $>5120$ & $>5120$ \\
18 & 320 & 80 & 80 & 80 & 640 \\
21 & 2560 & 2560 & $>5120$ & $>5120$ & 5120 \\
22 & 40 & nd & 640 & nd & 80 \\
25 & 80 & nd & 320 & nd & 40 \\
26 & $>5120$ & $>5120$ & $>5120$ & $>5120$ & $>5120$ \\
39 & 0 & nd & 40 & nd & 0 \\
42 & 1280 & 1280 & 2560 & $>5120$ & 1280 \\
44 & 1280 & nd & 5120 & nd & 2560 \\
46 & 40 & nd & 40 & nd & 40 \\
47 & nd & 2560 & 640 & $>5120$ & nd \\
49 & 0 & 0 & 0 & 0 & 0 \\
\hline
\end{tabular}

reference strains, and the marine isolate RBV-'Makah' from the USA.

When 5 of the $11 \mathrm{VHSV}$ isolates from the infected farm were used in 50\%PNT against sera from 16 fish from the same farm, no significant differences among the viruses were observed (Table 4).

\section{DISCUSSION}

All standardised and approved procedures for the diagnosis and surveillance of VHS are based on virus isolation in cell cultures inoculated with homogenized organ material from fish, followed by identification by serological or molecular methods. However, the detection of virus-specific antibodies in fish sera would have several advantages when compared with the traditional virus isolation and identification methods. While virus can usually only be isolated for a short period during the initial phase of the infection, humoral antibody response can be detected up to 1 yr after infection (Enzmann \& Konrad 1993). Moreover, sampling of test material can be done without sacrificing the fish, and fish sera are more stable for sending and storage than are virus isolates. The reasons why serological tests were not implemented for fish health surveillance a long time ago are that fish antibodies are more unstable and more likely to give false positive results than antibodies from mammals and birds; the time from infection to a detectable antibody response is very long ( 4 to $6 \mathrm{wk}$, depending on water temperature); and, finally, that the development of the anti- body response in fish is more variable than in mammals (Lorenzen \& LaPatra 1999).

The serological techniques most commonly used for the detection of fish antibodies against VHSV are $50 \%$ PNT, IF and ELISA (Olesen et al. 1991, Jørgensen et al. 1991, Ahne \& Jørgensen 1993). Other techniques such as WB (Lorenzen et al. 1993) or counter-current immunoelectrophoresis (Enzmann \& Konrad 1990, 1993) are less commonly used. In previous studies (Olesen et al.1991, Jørgensen et al. 1991), we compared 3 serological techniques for the detection of antibodies against VHSV and infectious hematopoietic necrosis virus (IHNV). Sera collected from rainbow trout that had been naturally or artificially infected with VHSV or IHNV were tested by ELISA, IF and $50 \%$ PNT. The most sensitive method for the detection of anti-IHNV antibodies was IF, while $50 \%$ PNT and ELISA were less sensitive. In the case of antibodies against VHSV, test sensitivity decreased in the following order: ELISA, IF and $50 \%$ PNT. However, a considerable number of sera contained cross-reacting antibodies, which could be considered as false-positive reactions, were detected by ELISA and IF but not by $50 \%$ PNT. The lower sensitivity of the $50 \%$ PNT was believed to be due to the fact that this method detects only neutralising antibodies that react with the viral glycoprotein (Olesen et al. 1991), whereas the other techniques detect antibodies directed against all the viral structural proteins. 50\% PNT was thus considered the least sensitive but the most specific of the tests. It was concluded that ELISA was the most suitable method for screening large numbers of sera due to its high sensitivity and reproducibility, and relatively low cost in terms of time and materials. IF and $50 \%$ PNT could be used to confirm the results, but are not recommended for large scale screening because they are time-consuming and require more technical expertise. In addition, $50 \%$ PNT is hampered by the need for fresh or properly stored trout serum that is free of neutralizing antibodies as a complement source.

In the present study, ELISA was far more sensitive than $50 \%$ PNT when using VHSV DK-F25. However, when $50 \%$ PNT was performed using one of the virus isolates from the farm, VHSV DK-201433-40 90\% of the sera were found positive, whereas only $61 \%$ were found positive by ELISA when using this same isolate.

When $50 \%$ PNT was used to examine selected sera against a broad panel of different VHSV isolates, significant differences in neutralisation titres were observed. Only one serogroup of VHSV exists when using poly- and monoclonal antibodies for typing (Olesen et al. 1993). We anticipated at that time that mammalian antibodies would be more exact and specific for uniform serological typing of the viruses than fish antibodies, due to fewer possibilities for diversification of 
antibody responses in lower vertebrates, as stressed by Du Pasquier (1982). It was therefore surprising to observe that a change of VHSV isolate in a $50 \%$ PNT test could change the number of positive trout sera from 0 to $90 \%$, and furthermore to observe the significant differences in titres of 5 selected rainbow trout sera against different VHSV isolates. This could reflect a much more refined and specific humoral antibody response in fish than previously recorded. However, when examining different virus isolates from the same farm, all titres obtained were similar, reflecting the high homology of VHS viruses isolated from the same site and VHS outbreak (Einer-Jensen et al. 2004).

The specificity of the tests used was high and only one low-titre false-positive reaction was observed in ELISA using the DK-F25 strain on 50 negative control sera from a farm free of VHS. No false positives were observed in $50 \%$ PNT or ELISA with the homologous VHSV.

In the present work, VHSV could be isolated from 11 broodfish with no clinical signs of diseases. Serum antibodies might bind to VHSV in vivo and give falsenegative virus isolations, but the fact that some fish were positive for both VHSV and anti-VHSV antibodies, with both low and high titres, might indicate that the antibody blocking of viruses does not play in important role in virus isolation. The existence of fish with both VHSV in the tissue and significant levels of anti-VHSV antibodies (e.g. Trout No. 15 and 42) indicates that humoral immunity is not sufficient for a complete neutralisation of virus in infected fish.

An end-point serum neutralisation test, which is easier to perform and more suitable for processing large numbers of serum samples, was developed by Hattenberger-Baudouy et al. (1995). In a large-scale serological survey conducted in France, which involved 229 farms and in which more than 14000 trout sera were analysed, the relationship between the serum-neutralizing antibody of the fish and the presence of VHSV and/or IHNV in a trout farm population was confirmed by this method. Thus, this technique was recommended for epidemiological studies and could be useful in the implementation of fish surveillance programmes. However, it is obvious from our results that the VHSV isolate used in neutralisation tests plays a very important role in the outcome of the tests. The VHSV DK-F25 belonging to neutralisation pattern Type I had been used in $50 \%$ PNT at our laboratory since 1984, because trout sera at that time were shown to give higher titres with that isolate than with several other VHSV isolates tested (Olesen \& Jørgensen 1986). However, in this study, the homologous neutralisation pattern Type III isolate was much more efficient in detecting antibodies against VHSV than DK-F25 or DK-F1 in $50 \%$ PNT. Therefore, if a standardised neu- tralisation test is to be recommended in future surveillance of VHS, it is necessary to first be aware of which virus isolates are to be used.

With regard to $50 \% \mathrm{PNT}$, the reaction is dependent on the ability of fish antibodies to recognise a few neutralising epitopes on the viral glycoprotein (Lorenzen \& LaPatra 1999), while a broad range of viral antigens are putative binding sites for fish antibodies in ELISA (and IF) tests. It was therefore anticipated that only a minor effect would be observed if different VHSV isolates were used in ELISA. Use of the homologous VHSV in ELISA instead of the traditional DK-F25 strain did not increase the number of positives; on the contrary, the number of positive sera decreased by $20 \%$. This might be due to fewer antigens presenting epitopes in the preparation of the detergent-treated homologous virus suspension compared with the DKF25 virus preparations, or to the simple fact that different amounts of virus were used in the 2 ELISAs.

Previous studies have demonstrated that conventional WB assay is inadequate for detecting an antibody response to natural VHSV infection. This is possibly due to the negative, denaturing effect of mercaptoethanol on protein conformation, which eliminates the tertiary structure and allows the antibodies to attach only to linear epitopes; in contrast to this, rainbow trout tend to produce antibodies that only recognize discontinuous epitopes (Lorenzen et al. 1993). Lorenzen et al. (1993) reported that WB assays revealed that rainbow trout are able to produce antibodies that recognize all viral proteins of VHSV, but this usually only occurred after repeated immunization of fish with whole virus particles. In this study, we found that $61 \%$ of the sera recognized at least one of the VHSV proteins, the same percentage that was found to be positive in ELISA using the DK-F25 strain. One interesting finding is that 29 sera reacted with the glycoprotein of the VHSV DKF1 strain used in WB, whereas none of the sera showed neutralizing antibodies when assessed by $50 \%$ PNT using the same VHSV isolate. This indicates that the sera recognised epitopes on the viral glycoprotein that were not neutralising this particular virus. The neutralisation of VHSV is specifically related to antibodies binding to the glycoprotein (Lorenzen \& LaPatra 1999).

To conclude, in terms of laboratory equipment, ELISA is more suitable to use in generalised laboratories than are neutralisation tests. ELISA is usually very sensitive, rapid, independent of complement and costeffective for analysing high numbers of sera. However, the variable specificity of the ELISA test makes the neutralisation test the technique of choice for the screening of non-infected populations where falsepositive reactions could have damaging consequences. False-positive sera usually have a low titre, so the criteria for defining a positive sample must be consid- 
ered carefully. The end-point neutralisation test may be easier for most laboratories to use than $50 \%$ PNT. In any case, the choice of virus strain is extremely important for the outcome of neutralisation tests, and should reflect the most recent and common type of virus in the area.

Acknowledgements. We thank the technicians at DFVF for their help, especially M. Eliassen and N. Nicolaisen. We also acknowledge our colleagues at DFVF for their contribution to this study. J.M.F.G. was the recipient of a postdoctoral research fellowship from 'Secretaría de Estado de Educación y Universidades, Ministerio de Educación, Cultura y Deporte' of Spain, and was co-financed by the European Social Program.

\section{LITERATURE CITED}

Ahne W, Jørgensen PEV (1993) Prevalence of neutralising antibodies to IHNV and VHSV in free-living and cultured rainbow trout in Germany. Bull Eur Assoc Fish Pathol 13: $7-9$

Anon. (1991) Council Directive 91/67/EEC of 28 January 1991 concerning the animal health conditions governing the placing on the market of aquaculture animals and products. Off J Eur Comm L046:1-18

Anon. (2001) Commission Decision 2001/183/EC of 22 February 2001 laying down the sampling plans and diagnostic methods for the detection and confirmation of certain fish diseases. Off J Eur Comm L067: 65-76

Brunson R, True K, Yancey J (1989) VHS virus isolated at Makah National Fish Hatchery. Am Fish Soc Fish Health Sect Newsl 17:3-4

de Kinkelin P, Bearzotti M (1981) Immunization of rainbow trout against viral hemorrhagic septicemia (VHS) with a thermoresistant variant of the virus. Dev Biol Stand 49: 431-439

Du Pasquier L (1982) Antibody diversity in lower vertebrates: why is it so restricted? Nature 296:11-313

Einer-Jensen K, Ahrens P, Forsberg R, Lorenzen N (2004) Evolution of the fish rhabdovirus viral haemorrhagic septicaemia virus. J Gen Virol 85:1167-1179

Enzmann PJ, Konrad M (1990) Antibodies against VHS in whitefish of the Lake of Constance, West Germany. Bull Eur Assoc Fish Pathol 10:24-25

Enzmann PJ, Konrad M (1993) Longevity of antibodies in brown trout and rainbow trout following experimental infection with VHS-virus. Bull Eur Assoc Fish Pathol 13: 193-194

Fijan N, Sulimanovic D Bearzotti M, Muzinic D, Zwillenberg LO, Chilmonczyk S, Vautherot JF, de Kinkelin P (1983) Some properties of the epithelioma papulosum cyprini (EPC) cell line from carp (Cyprinus carpio). Ann Virol Inst Pasteur 134 E:207-220

Hattenberger-Baudouy AM, Dalton M, Merle G, de Kinkelin $P$ (1995) Serum neutralization test for epidemiological studies of salmonid rhabdoviroses in France. Vet Res 26: $512-520$

Jensen MH (1965) Research on the virus of Egtved disease. Ann NY Acad Sci 126:422-426

Jørgensen PEV (1971) Egtved virus: demonstration of neutralizing antibodies in serum from artificially infected rainbow trout (Salmo gairdneri). J Fish Res Board Can 28:875-878

Jørgensen PEV (1974) Indirect fluorescent antibody techniques for demonstration of trout viruses and corresponding antibodies. Acta Vet Scand 15:198-205
Jørgensen PEV, Olesen NJ, Lorenzen N, Winton JR, Ristow SS (1991) Infectious hematopoietic necrosis (IHN) and viral hemorrhagic septicemia (VHS): detection of trout antibodies to the causative viruses by means of plaque netralization, immunofluorescence, and enzymelynked immunosorbent assay. J Aquat Anim Health 3: 100-108

LaPatra SE (1996) The use of serological techniques for virus surveillance and certification of finfish. Annu Rev Fish Dis 6:15-28

Lorenzen N, LaPatra SE (1999) Immunity to rhabdoviruses in rainbow trout: the antibody response. Fish Shellfish Immunol 9:345-360

Lorenzen N, Olesen NJ, Jørgensen PEV (1988) Production and characterization of monoclonal antibodies to four Egtved virus structural proteins. Dis Aquat Org 4:35-42

Lorenzen N, Olesen NJ, Jørgensen PEV (1990) Neutralization of Egtved virus pathogenicity to cell cultures and fish by monoclonal antibodies to the viral G protein. J Gen Virol 71:561-567

Lorenzen N, Olesen NJ, Jørgensen PEV (1993) Antibody response to VHS virus proteins in rainbow trout. Fish Shellfish Immnunol 3:461-473

Mortensen HF, Heuer OE, Lorenzen N, Otte L, Olesen NJ (1999) Isolation of viral haemorrhagic septicaemia virus (VHSV) from wild marine fish species in the Baltic Sea, Kattegat, Skagerrak and the North Sea. Virus Res 63: 95-106

OIE (Office International des Epizooties) (2004) International aquatic animal health code, 7 th edn. Office International des Epizooties, Paris

Olesen NJ, Jørgensen PEV (1986) Detection of neutralizing antibody to Egtved virus in rainbow trout (Salmo gairdneri) by plaque neutralization test with complement addition. J Appl Ichthyol Z Angew Ichthyol 2:33-41

Olesen NJ, Jørgensen PEV (1991) Rapid detection of viral haemorrhagic septicaemia virus in fish by ELISA. J Appl Ichthyol Z Angew Ichthyol 7:183-186

Olesen NJ, Lorenzen N, Jørgensen PEV (1991) Detection of rainbow trout antibody to Egtved virus by enzyme-linked immunosorbent assay (ELISA), immunofluorescence (IF), and plaque neutralization tests $(50 \%$ PNT). Dis Aquat Org 10:31-38

Olesen NJ, Lorenzen N, Jørgensen PEV (1993) Serological differences among isolates of viral haemorrhagic septicaemia virus detected by neutralizing monoclonal and polyclonal antibodies. Dis Aquat Org 16:163-170

Skall HF, Olesen NJ, Mellergaard S (2005) Viral haemorrhagic septicaemia virus in marine fish and its implications for fish farming - a review. J Fish Dis 28:509-529

Thuvander A, Fossum C, Lorenzen N (1990) Monoclonal antibodies to salmonid immunoglobulin: characterization and applicability in immunoassays. Dev Comp Immunol 14: 415-423

Van Regenmortel MHV, Fauquet CM, Bishop DHL, Carstens EB and 7 others (2000) Virus taxonomy: classification and nomenclature of viruses - seventh report of international committee on taxonomy of viruses. Academic Press, San Diego, CA

Voller A, Binwell DE, Bartlett A (1979) The enzyme-linked immunosorbent assay (ELISA). A guide with abstract of microplate applications. Dynatech Europe, Guernsey

Wolf K (1988) Fish viruses and fish viral diseases. Cornell University Press, Ithaca, NY

Wolf K, Gravel M, Malsberger RG (1966) Lymphocystis virus: isolation and propagation in centrarchild fish cell lines. Science 151:1004-1005 